\title{
Features of atherosclerosis of common carotid arteries among black Kenyans
}

\author{
OGENG'O, J., ONGETI, K. and MWACHAKA, P.*
}

\author{
Department of Human Anatomy, University of Nairobi, P.O. Box 30197 - 00200, Nairobi, Kenya \\ ${ }^{*}$ E-mail: pmaseghe@gmail.com
}

\begin{abstract}
Introduction: Data on the features of atherosclerosis of common carotid artery are important for informing strategies against ischaemic stroke in Subsaharan Africa, but are scarce. Materials and Methods: This study therefore investigated, by light microscopy, the presence of features of atherosclerosis in the left common carotid artery among 108 black Kenyans [76 males; 32 females; Mean age 36.4, range 22-82 years] who suffered violent death. Specimens from the distal segment of the artery were prepared for routine paraffin embedding, and $5 \mu$ sections stained with Mason's Trichome. Results: At least one feature of atherosclerosis was observed in $22(20.4 \%)$ cases. Intimal hyperplasia alone was present in all the 22 cases followed by Intimal hyperplasia and degeneration of internal elastic lamina 19 (17.6\%); Intimal hyperplasia combined with disintegration of internal elastic lamina and medial degeneration 17 (15.7\%). Thickening of tunica adventitia with neovascularization were present in $8(7.4 \%)$ of cases. All the features were more frequent in males than females $(1.4: 1)$ and those over 40 years old. Eight of the cases $(36.4 \%)$ were in individuals aged below 40 years. Conclusion: Multiple features of atherosclerosis in common carotid artery are present in over $20 \%$ of the asymptomatic black Kenyans studied. They occur more frequently in males, and affect individuals younger than 40 years. These features appear in all three layers of the vessel wall, suggesting that the disease has attained several stages of severity in this population. We recommend early screening for the disease in individuals at risk.
\end{abstract}

Keywords: common carotid, atherosclerosis, black Kenyans.

\section{Introduction}

Atherosclerosis of the common carotid artery (CCA) is one of most common causes of ischaemic stroke (HANDA, MATSUMOTO, MAEDA et al., 1995; NAGAI, KITAGAWA, SAKAGUCHI et al., 2001). This condition is on the increase in Sub Saharan Africa, including Kenya (MENSAH, 2008; TRUELSON, 2010). Data on the features of atherosclerosis in the common carotid arteries are important in enhancing understanding of this disease and hence its mitigation strategies. We recently demonstrated the existence of anatomical risk factors for common carotid atherosclerosis in a substantial proportion of Kenyans (OGENG'O, ONGETI, MALEK et al., 2013 ) features of atherosclerosis in the tunica adventitia of the CCA in nearly $10 \%$ of the population (OGENG'O, ONGETI, OBIMBO et al., 2014). Further, atherogenic changes in the common carotid artery are important predictors of atherosclerosis in other vascular beds (DARABIAN, HORMUZ, LATIF et al., 2013). The magnitude of atherosclerosis shows regional, geographic and ethnic variations (KHAN, NAQVI, BANSARI et al., 2011; MIRANDA, BERNADE-ORTIZ, SMEETH et al., 2012; PU, LIU, WANG et al., 2013). Until recently, this disease was considered uncommon in Subsaharan Africa. Recent studies, however, indicate a steep rise in atherosclerosis (OLADAPO, OLUSAKIN, AKANG et al., 2013). Indeed, stroke is a major cause morbidity and mortality in Kenya (MULI and RHODA, 2013). In order to mitigate further rise, there is need for more reports on atherosclerosis of common carotid arteries. In view of the heavy burden of stroke in Africa, several mitigation strategies have been proposed mainly on prevention, surveillance and rehabilitation. (OWOLABI, 2011). Implementation of these strategies requires histopathological data. This study therefore examined the common carotid arteries of black Kenyans for the presence of features of atherosclerosis.

\section{Materials and Methods}

Materials for this study were obtained from 108 left common carotid arteries of adult black Kenyans [76 males, 32 females; Mean age 34.6 years, (range 22-82)] during autopsy at the Department of Human Anatomy, University of Nairobi. Only arteries without macroscopic features of atherosclerosis were included in the study.

Specimens were taken within 72 hours of death, to avoid overt postmortem damage to the tissues. Two millimeter long specimens were taken from the distal left common carotid artery. They were fixed by immersion in 10\% formaldehyde solution for three days, then trimmed and processed routinely for paraffin embedding. Five micrometer sections were stained with Mason's trichrome stain for demonstration of mural components and features of atherosclerosis. The slides were then examined at various magnifications, using a light microscope. Micrographs were taken using a high resolution digital camera.

They were analysed for age and gender, using statistical programme for social science (SPSS) version 17.0. The data are presented using tables and micrographs. 


\section{Results}

Six features of atherosclerosis were identified in 22 (20.4\%) of the cases: namely intimal hyperplasia, disintegration of internal elastic lamina (IEL), medial degeneration, disintegration of elastic lamellae, adventitial thickening and adventitial hypervascularity. The one present in all the 22 cases was intimal hyperplasia. It was combined with disintegration of IEL in 19 (17.6\%). The various combinations of features are shown in Table 1.

In $15(13.9 \%)$ of the cases the intimomedial thickness (IMT) was mainly due to thickening of the tunica media (Figure la). In the remainder of cases, there was moderate (Figure lb) to severe intimal hyperplasia. Cases of severe hyperplasia also showed other features reminiscent of atherosclerosis, namely presence of inflammatory cells, intimal neovascularization, disintegration of internal elastic lamina, disintegration of elastic lamellae and medial fibrosis (Figure lc). In 13 (12\%) of cases, the thickened intima also showed fatty degeneration and areas of localized inflammatory cell infiltration (Figure ld). In $17(15.7 \%)$ cases, the IEL had ruptured, bringing the tunica intima and tunica media in direct contact. In these cases, both intima and media appeared fibrotic and disorganized (Figure le). Some cases of mild intimal thickening and medial fibrosis were associated with profuse proliferation of vasa vasora in the thickened tunica adventitia (Figure lf).

\subsection{Age and gender distribution}

Of the 22 cases that showed features of atherosclerosis, the mean age was 42.3 years, peaking between 41-50 years. Majority $(63.6 \%)$ were aged 50 years and less, Eight cases $(36.4 \%)$ were aged 40 years and less. The male:female ratio was $1.4: 1$ (Table 2)

Table 1. Frequency of features of atherosclerosis in left common carotid arteries among black Kenyans $(\mathrm{N}=108)$.

\begin{tabular}{lccc}
\hline \multicolumn{1}{c}{ Feature } & Frequency (\%) & Male & Female \\
\hline $\mathbf{1}$ alone & $22(20.4)$ & 13 & 09 \\
$\mathbf{1 + 2}$ alone & $19(17.6)$ & 11 & 08 \\
$\mathbf{1 + 2 + 3}$ & $17(15.7)$ & 10 & 07 \\
$\mathbf{1 + 2 + 3 + 4}$ & $16(14.8)$ & 09 & 07 \\
$\mathbf{1 + 3 + 5}$ & $14(13.0)$ & 08 & 06 \\
$\mathbf{4 + 5 + 6}$ & $12(11.1)$ & 07 & 05 \\
$\mathbf{5 + 6}$ alone & $08(7.4)$ & 05 & 03 \\
\hline
\end{tabular}

1 - Intimal hyperplasia; 2 - Disintegration of IEL; 3 - Medial degeneration; 4 - Disintegration of elastic lamellae; 5 - Adventitial thickening; 6 - Adventitial hypervascularity.

Table 2. Age and gender distribution of individuals with features of atherosclerosis of CCA among black Kenyans $(\mathrm{N}=22)$.

\begin{tabular}{cccc}
\hline \multirow{2}{*}{ Age } & Frequency & \multirow{2}{*}{ Female } & Total \\
\cline { 2 - 2 } & Male & & 3 \\
$21-30$ & 2 & 1 & 5 \\
$31-40$ & 3 & 2 & 6 \\
$41-50$ & 4 & 2 & 3 \\
$51-60$ & 2 & 1 & 4 \\
$61-70$ & 2 & 2 & 1 \\
$71-80$ & 0 & 1 & \\
\hline
\end{tabular}

\section{Discussion}

Features of atherosclerosis were present in over $20 \%$ of those studied. This is only slightly lower than $25 \%$ in the Caucasian populations (GOUBERGRITS, AFFELD, FERNANDEZ-BRITTO et al., 2001), but comparable to $22.5 \%$ among Nigerians (ERETE, OGUN, OLADAPO et al., 2012). This indicates that the burden of atherosclerosis in the carotid arteries among black Africans is comparable to that in Caucasian populations. This is concordant with studies in other

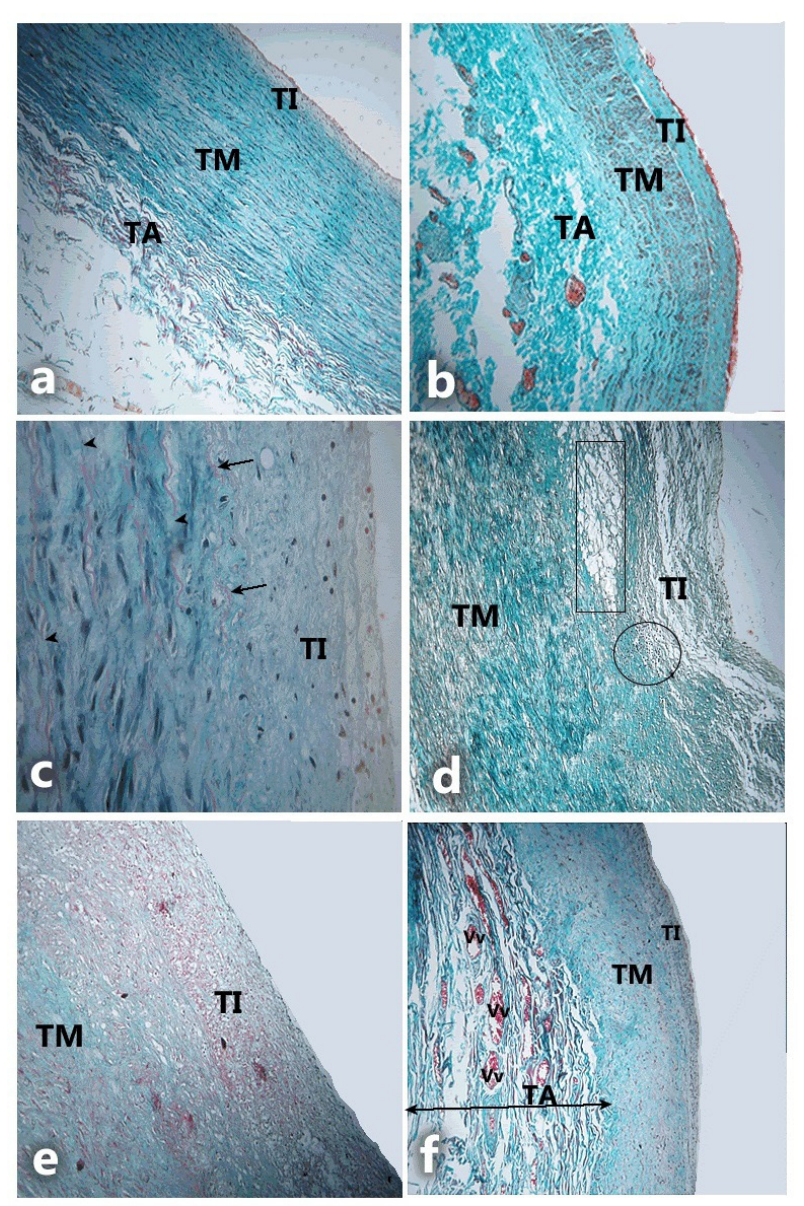

Figure 1. F: Features of atherosclerosis in the left common carotid arterial wall among black Kenyans. Mason's Trichome stain. $\mathrm{TI}=$ Tunica Intima; $\mathrm{TM}=$ Tunica Media; $\mathrm{TA}=$ Tunica Adventitia. (a) Wall of common carotid artery in a 27 year old female showing all three tunics. Note the tunica media contributing over $80 \%$ of IMT; (b) Full wall thickness of CCA in a 43 year old male with TI occupying about $40 \%$ and TM occupying $60 \%$ of IMT. Note also the prominent TA. x 100 ; (c) Marked hypertrophy of the TI in a 57 year old male. Note the cellular infiltration; disintegration of internal elastic lamina (arrows). The elastic lamellae of the tunica media also show areas of fragmentation (arrow heads). x 400; (d) TI and TM, in a 47 year old female. The TI occupies equal proportion as the TM. Note the intimal fatty degeneration (rectangle) and inflammatory cell proliferation (circle). x 100; (e) Complete rupture of IEL in a 59 year old male bringing the TI and TM into direct contact. Note the disorganization and fibrosis of both tunica intima and media. $\mathrm{x}$ 400; (f) Full wall thickness in a 39 year old male showing mild intimal hyperplasia (TI), degenerating TM, marked thickening of TA and proliferation of vasa vasora (vv). x 100. 
African countries (OLADAPO, OLUSAKIN, AKANG et al., 2013). Measures should therefore be instituted to curtail escalation of this condition.

The most prevalent feature was intimal hyperplasia which has been correlated with presence of risk factors for atherosclerosis (CIZEK, BEDRI, TALUSAN et al., 2007). Its existence in the Kenyan population is consistent with presence of risk factors similar to those present in other populations (KAMOTHO, OGOLA, JOSHI et al., 2004; MATHENGE, FORSTER and KUPER, 2010). Besides intimal hyperplasia and significant percent stenosis, other features of atherosclerosis observed in this study included the following: intimal hypercellularity, disintegration of IEL, medial degeneration, mural neovascularization and adventitial thickening. Intimal hypercellularity is usually due to inflammatory lymphocytes, monocytes, macrophages, mast cells, smooth muscle cells and pericytes. Their increased number is caused by stimulation of their proliferative activity (OREKHOV, ANDREEVA, MIKHAILOVA et al., 1998; ZHDANOV, 1998) and migration of muscle cells from the tunica media (LIBBY, 2006). Distintegration of IEL occurs in advanced atherosclerosis (WONG and SCHREIBER, 1996; KWON, KIM, HONG et al., 1998; KONIARI, MARRILAS, PAPADAKI et al., 2011). Medial degeneration is caused by chronic apoptosis of vascular smooth muscle cells which accelerates atherogenesis and progression of atherosclerosis in the established plaques (CLARKE, LITTLEWOOD, FIGG et al., 2008). With progress of atherosclerosis, there is also extensive destruction of elastic lamellae (SELVIN, NAJJAR, CORNISH et al., 2010), focal necrosis (LAVEZZI, OTTAVIANI and MATTURRI, 2005) and fibrosis (MORENO , PURUSHOTHAMAN, FUSTER et al., 2002).

Adventitial thickness on the other hand occurs in advanced atherosclerosis because of inflammation and increased vascularization by vasa vasora (THIM, HAGENSEN, BENTZON et al., 2008; OGENG'O, ONGETI, OBIMBO et al., 2014). The presence of these features in various combinations is a strong indication that atherosclerosis is an established problem in the black Kenyan population.

The features were more common in males and females. This is consistent with literature reports that atherosclerosis and stroke are more common in men than in premenopausal women (PETREA, BEISER, SESHADRI et al., 2009; APPELROS, STEGMAYR and TERENT, 2009). In this population, over $30 \%$ of the individuals were aged 40 years and below, again consistent with reports that among black Africans, the disease occurs early (ALTADZHANOV, MUKOMENA, LAKHI et al., 2012). This suggests that stroke is likely to manifest early. Indeed reports indicate that stroke occurs $10-15$ years earlier in this population than in Caucasian ones (OGENG'O and OLABU, 2010). This implies that control measures, for example targeting lifestyle modification, in this population should be instituted early.

\section{Conclusion}

Multiple features of atherosclerosis are present in over $20 \%$ the carotid arteries of the asymptomatic black Kenyans studied. These features appear in all three layers of the vessel wall suggesting that the disease has attained several stages of progression. They occur early and are more common in males. Control measures should commence early.
Acknowledgements: We are grateful to Judith Machira, Margaret Irungu, Esther Mburu and Christopher Kamwaro for technical support and Antonina Odock - Opiko for typing this manuscript.

\section{References}

ALTADZHANOV, M., MUKOMENA, PN., LAKHI, S., ROSS, OA. and MESCHIA, JH. Stroke characteristics and outcome of adult patients admitted to the University Teaching Hospital, Lusaka, Zambia. The Open General \& Internal Medicine Journal, 2012, vol. 5, p. 3-8.

APPELROS, P., STEGMAYR, B. and TERENT, A. Sex differences in stroke epidemiology: a syptematic review. Stroke, 2009, vol. 40, n. 4, p. 1082-1090. PMid:19211488. http://dx.doi.org/10.1161/ STROKEAHA.108.540781.

CIZEK, SM., BEDRI, S., TALUSAN, P., SILVA, N., LEE, H. and STONE, JR. Risk factors for atherosclerosis and the development of preatherosclerotic intimal hyperplasia. Cardiovascular Pathology, 2007, vol. 16, n. 6, p. 344-350. PMid:18005873. http://dx.doi. org/10.1016/j.carpath.2007.05.007.

CLARKE, MC., LITTLEWOOD, TD., FIGG, N., MAGUIRE, JJ., DAVENPORT, AP., GODDARD, M. and BENNETT, MR. Chronic apoptosis of vascular smooth muscle cells accelerates and promotes calcification and medial degeneration. Circulation Research, 2008, vol. 102, n. 12, p. 1529-1538. PMid:18497329. http://dx.doi. org/10.1161/CIRCRESAHA.108.175976.

DARABIAN, S., HORMUZ, M., LATIF, MA., PAHLEVAN, S. and BUDOFF, MJ. The role of carotid intimal thickness testing and risk prediction in the development of coronary atherosclerosis. Current Atherosclerosis Reports, 2013, vol. 15, n. 3, p. 306. PMid:23328906. http://dx.doi.org/10.1007/s11883-012-0306-4.

ERETE, EI., OGUN, OG., OLADAPO, OO. and AKANG, EE. Prevalence and severity of atherosclerosis in extracranial carotid arteries in Nigeria: an autopsy study. BMC Cardiovascular Disorders, 2012, vol. 12, n. 1, p. 106. PMid:23153371. http://dx.doi.org/10.1186/14712261-12-106.

GOUBERGRITS, L., AFFELD, K., FERNANDEZ-BRITTO, J. and FALCON, L. Atherosclerosis lesions in the Human common carotid artery: a morphometric study of 31 specimens. Pathology, Research and Practice, 2001, vol. 197, n. 12, p. 803-809. PMid:11795827. http://dx.doi.org/10.1078/0344-0338-00163.

HANDA, N., MATSUMOTO, M., MAEDA, H., HOUGAKU, H. and KAMADA, T. Ischaemic stroke events and carotid atherosclerosis: results of the Osaka Follow up study for Ultrasonographic Assessment of carotid Atherosclerosis (the OSAKA study). Stroke, 1995, vol. 26, n. 10, p. 1781-1786.

KAMOTHO, C., OGOLA, EO., JOSHI, M. and GIKONYO, D. Cardiovascular risk factor profile of black Africans undergoing coronary angiography. East African Medical Journal, 2004, vol. 81, n. 2, p. 8286. PMid:15125091. http://dx.doi.org/10.4314/eamj.v8li2.9130.

KHAN, M., NAQVI, I., BANSARI, A. and KAMAL, AK. Intracranial Atherosclerotic disease. Stroke Research and Treatment, 2011, vol. 2011, p. 1-13. http://dx.doi.org/10.4061/2011/282845.

KONIARI, I., MARRILAS, D., PAPADAKI, H., KARANIKOLAS, M., MANDELLOU, M., PAPALOIS, A., KOLETSIS, E., DOUGENIS, D. and APOSTOLAKIS, E. Structural and biomechanical alterations in rabbit thoracic aortas are associated with progression of atherosclerosis. Lipids in Health and Disease, 2011, vol. 10, n. 1, p. 125. PMid:21791107. http://dx.doi.org/10.1186/1476-511X-10-125.

KWON, HM., KIM, D., HONG, BK., BYUN, KH., OH, SH., KNA, JS., KIM, HS., SCHWARTZ, RS. and LERMAN, A. Ultrastructural changes of the internal elastic lamina in experimental hypercholestrolemic porcine coronary arteries. Journal of Korean Medical Science, 1998, 
vol. 13, p. 603-611. PMid:9886168. http://dx.doi.org/10.3346/ jkms.1998.13.6.603.

LAVEZZI, AM., OTTAVIANI, G. and MATTURRI, L. Biology of the smooth muscles in human atherosclerosis. Acta Pathologica, Microbiologica, Et Immunologica Scandinavica, 2005, vol. 113, p. 112-121.

LIBBY, P. Inflamation and cardiovascular disease mechanisms. The American Journal of Clinical Nutrition, 2006, vol. 83, n. 2, p. 45654605. PMid:16470012.

MATHENGE, W., FORSTER, A. and KUPER, H. Urbanization, ethnicity and cardiovascular risk in a population transition in Nakuru, Kenya: a population based survey. BMC Public Health, 2010, vol. 10, n. 1, p. 569. PMid:20860807. http://dx.doi.org/10.1186/14712458-10-569.

MENSAH, G. Epidemiology of stroke and high blood pressure in Africa. Heart, 2008, vol. 94, n. 6, p. 697-705. PMid:18308869. http://dx.doi.org/10.1136/hrt.2007.127753.

MIRANDA, JJ., BERNADE-ORTIZ, A., SMEETH, L., GILMAN, RH. and CHECKLEY, W. Addressing geographical variation in the progression of non - communicable diseases in Peru: the CRONICAS Cohort - study protocol. BMJ Open, 2012, vol. 2, n. 1, p. 2. PMid:22240652.

MORENO, PR., PURUSHOTHAMAN, KR., FUSTER, V. and O'CONNOR, WN. Intimomedial interphase damage and adventitial inflammation is increased beneath disrupted atherosclerosis in the aorta. Circulation, 2002, vol. 105, p. 2504-2511. PMid:12034657.

MULI, G. and RHODA, A. Quality of life among young adults with stroke living in Kenya. African Health Sciences, 2013, vol. 13, n. 3, p. 632-638. PMid:24250300.

NAGAI, Y., KITAGAWA, K., SAKAGUCHI, M., SHIMIZU, Y., HASHIMOTO, H., YAMAGAMI, H., NARITA, M., OHTSUKI, T., HORI, M. and MATSUMOTO, M. Significance of earlier carotid Atherosclerosis for stroke subtypes. Stroke, 2001, vol. 32, n. 8, p. 1780-1785. PMid:11486105. http://dx.doi.org/10.1161/01. STR.32.8.1780.

OGENG'O, J. and OLABU, BO. Cortical stroke in Kenya. International Journal of Stroke, 2010, vol. 5, n. 6, p. 514-518. PMid:21050415. http://dx.doi.org/10.1111/j.1747-4949.2010.00530.x.

OGENG'O, J., ONGETI, KW., MALEK, A., WERE, FN., MISIANI, M., WAISIKO, B., et al Anatomical risk factors for atherosclerosis of left common carotid artery in a black Kenyan population. Research Open Journal of Anatomy, 2013, vol. 1, n. 1, p. 1-7.

OGENG'O, J., ONGETI, K., OBIMBO, M., OLABU, B. and MWACHAKA, P. Features of atherosclerosis in the tunica adventitia of coronary and carotid arteries in a black Kenyan population. Anatomy
Research International, 2014, vol. 2014, p. 1-5. http://dx.doi. org/10.1155/2014/456741.

OLADAPO, OO., OLUSAKIN, J., AKANG, E. and OGUN, GO. Atherosclerosis of the intracranial carotid arteries in Nigerians: a pilot Autopsy study. Nigerian Journal of Cardiology, 2013, vol. 10, n. 2, p. 62-67. http://dx.doi.org/10.4103/0189-7969.127002.

OREKHOV, AN., ANDREEVA, ER., MIKHAILOVA, IA. and GORDON, D. Cell proliferation in normal and atherosclerotic human aorta: proliferative splash in lipid - rich lesions. Atherosclerosis, 1998, vol. 139, n. 1, p. 41-48. PMid:9699890. http://dx.doi.org/10.1016/ S0021-9150(98)00044-6.

OWOLABI, MO. Taming the burgeoning stroke epidemic in Africa: Stroke quadrangle to the rescue. The West Indian Medical Journal, 2011, vol. 60, n. 4, p. 412-421. PMid:22097671.

PETREA, RE., BEISER, AS., SESHADRI, S., KELLY-HAYES, M., KASE, CS. and WOLF, PA. Gender differences in stroke incidence and post stroke disability in the framingham heart study. Stroke, 2009, vol. 40, p. 1032-1037. PMid:19211484. http://dx.doi.org/10.1161/ STROKEAHA.108.542894.

PU, Y., LIU, L., WANG, Y., ZOU, X., PAN, Y., SOO, Y., LEUNG, T., ZHAO, X., WONG, KS. and WANG, Y. Geographic and sex difference in the distribution of intracranial atherosclerosis in China. Stroke, 2013, vol. 44, n. 8, p. 109-114. PMid:23760212.

SELVIN, E., NAJJAR, SS., CORNISH, TC. and HALUSHKA, MK. A comprehensive histopathological evaluation of medial fibrosis: Insights into the pathophysiology of arterial stiffering. Atherosclerosis, 2010, vol. 208, p. 69-74. PMid:19632677. http://dx.doi.org/10.1016/j. atherosclerosis.2009.06.025.

THIM, T., HAGENSEN, MK., BENTZON, JF. and FALK, E. From vulnerable plaque to atherothrombosis. Journal of Internal Medicine, 2008, vol. 263, n. 5, p. 506-516. PMid:18410594. http://dx.doi. org/10.1111/j.1365-2796.2008.01947.x.

TRUELSON, T. Stroke incidence studies in Africa. Lancet Neurology, 2010, vol. 9, n. 1, p. 755-757.

WONG, CB. and SCHREIBER, TL. Acute myocardial infarction in a patient with Von Willebrand disease. Catheterization and Cardiovascular Diagnosis, 1996, vol. 38, n. 3, p. 287-288. PMid:8804764. http:// dx.doi.org/10.1002/(SICI)1097-0304(199607)38:3<287::AIDCCDI6>3.0.CO;2-E.

ZHDANOV, VS. The role of hyperplasia of the arterial intima in human atherogenesis. Arkhiv Patologii, 1998, vol. 60, n. 6, p. 8-13. PMid:9949897. 